\title{
Hell Roaring Creek. Into-the-jug (geworfen)
}

\section{Lucien Castaing-Taylor}

\section{OpenEdition}

\section{Journals}

Édition électronique

URL : http://journals.openedition.org/actesbranly/447

DOI : $10.4000 /$ actesbranly. 447

ISSN : 2105-2735

Éditeur

Musée du quai Branly Jacques Chirac

\section{Référence électronique}

Lucien Castaing-Taylor, « Hell Roaring Creek. Into-the-jug (geworfen) », Les actes de colloques du musée du quai Branly Jacques Chirac [En ligne], 2 | 2009, mis en ligne le 21 décembre 2009, consulté le 08 septembre 2020. URL : http://journals.openedition.org/actesbranly/447 ; DOI : https://doi.org/ 10.4000/actesbranly.447

Ce document a été généré automatiquement le 8 septembre 2020

(c) Tous droits réservés 


\title{
Hell Roaring Creek. Into-the-jug (geworfen)
}

\author{
Lucien Castaing-Taylor
}

1 Le projet comprenant une totalité de neuf vidéos que je voudrais décrire, a débuté en 2001 et prend fin en 2009. Bien qu'ils aient été conçus comme des entités autonomes, je pense que Hell Roaring Creek - on pourrait dire en français quelque chose comme « la rivière de l'enfer qui aboie » - que j'ai montré a la Marian Goodman Gallery à New York l'année dernière, mais pas encore en Europe, et Into-the-jug (geworfen) (pichet/ carafe/ prison/ poitrine) peuvent être pensés comme une "paire ", et c'est d'ailleurs comme cela qu'ils ont été installés, recto verso, dans la James gallery a New York cet automne. Ils font partis d'une trentaine de films, vidéos, et travaux sonores qui ont été produits au Laboratoire d'Ethnographie Sensorielle (SEL) à Harvard depuis sa création il y a 3 ans. L'idée a l'origine du SEL était de créer un espace permettant la conception de travaux qui jusque là étaient inhibés, pour ne pas dire prohibés, par les inclinations dominantes a la fois de l'anthropologie, de l'art et aussi du documentaire. Dans ce petit préambule, je voudrais simplement essayer de m'expliquer un peu sur ce point.

2 Il n'y a pas de manifestes au SEL. Pas plus qu'il n'y a de principes dogmatiques qui guident ses productions. Et nous ne souhaitons pas plus qu'il y ait ce qui serait un «air de famille " parmi les travaux produits sous son égide. Mais, au moins pour le moment, je crois qu'on peut raisonnablement faire ces 3 propositions. D'une part, SEL est apparemment plus attaché au «réel» que la plupart de l'art, en particulier l'art conceptuel. SEL s'attache en effet a une forme d'expression qui est en quelque sorte adéquate a l'ampleur de l'expérience humaine. Et concernant ce point, s'il nous fallait nous trouver un manifeste, ou une bible, ce serait sûrement le livre de John Dewey, magnifiquement négligé. Je parle de son livre L'art comme expérience, critiqué dès sa sortie en 1934, pour être trop Hégélien par certains, et, comme étant un plagiat par d'autres, et enfin, sereinement ignoré par la plupart des théoriciens de l'esthétique, et par absolument tous les anthropologues de l'art depuis sa parution. Je n'ai pas lu un seul travail d'anthropologue de l'art qui révèle une connaissance de ce livre, et je me demande pourquoi. Il y a sûrement au moins 2 principales raisons. 
Premièrement, Dewey prend comme sujet, bien qu'il n'utilise pas ce terme lui-même, la phénoménologie de l'expérience esthétique - une expérience qui, si quelque chose doit être au centre, est très sûrement au cœur de l'existence humaine, mais que les anthropologues de l'art ont réussi à prodigieusement négliger, trop occupés qu'ils sont à réduire les manifestations de l'être à de la simple signification, et à réduire l'art à autant d'épiphénomènes de telle ou telle culture, à de la simple "culture matérielle ", ou a quelque chose d'analogue aux rituels, etc.

Deuxièmement, Dewey est profondément investi dans la nature, en associant de façon récurrente l'expérience esthétique pas simplement à l'expérience de la vie quotidienne, mais aussi à ses sources animalières infrahumaines, et à l'interaction à la fois sous- et supra cutanée entre ce qu'il appelle 3 décennies avant l'invention du mot «cyborg ", la constitution de la "créature vivante" et son "environnement", alors même que parler de la nature, pour les pratiquants de l'anthropologie culturelle et sociale a depuis longtemps été source d'embarras - être désavoué, immédiatement transformé en " seconde nature ", médiatisé de part en part par la culture, une simple construction sociale, ou une idéologie politique ou scientifique dangereuse à combattre activement, et ainsi de suite. Comme Dewey, et au contraire de nos collègues anthropologues, SEL se soucie, non pas d'analyser, mais de produire activement de l'expérience esthétique sans nous laisser avec l'illusion de « comprendre » l'expérience quotidienne. SEL n'a pas non plus peur de transcender ce qui est souvent considéré comme le territoire particulière des humains, et de fouiller la nature - en bref, re-conjuguer culture et nature, continuer à traquer les promiscuités entre notre «moi " animal et non animal, et de nous restituer à la fois au domaine de la perception dans toute sa plénitude, plutôt que de nous proposer le jeu académique que Dewey appelle "re-connaissance ", et de nous restituer: aussi au royaume de la « chair ». Dans l'heureuse phrase de Merleau-Ponty, $L$ ' être sauvage dans laquelle l'invisible, loin d'être la négation ou la contradiction du visible, est en fait son « partageur de secret », sa membrure.

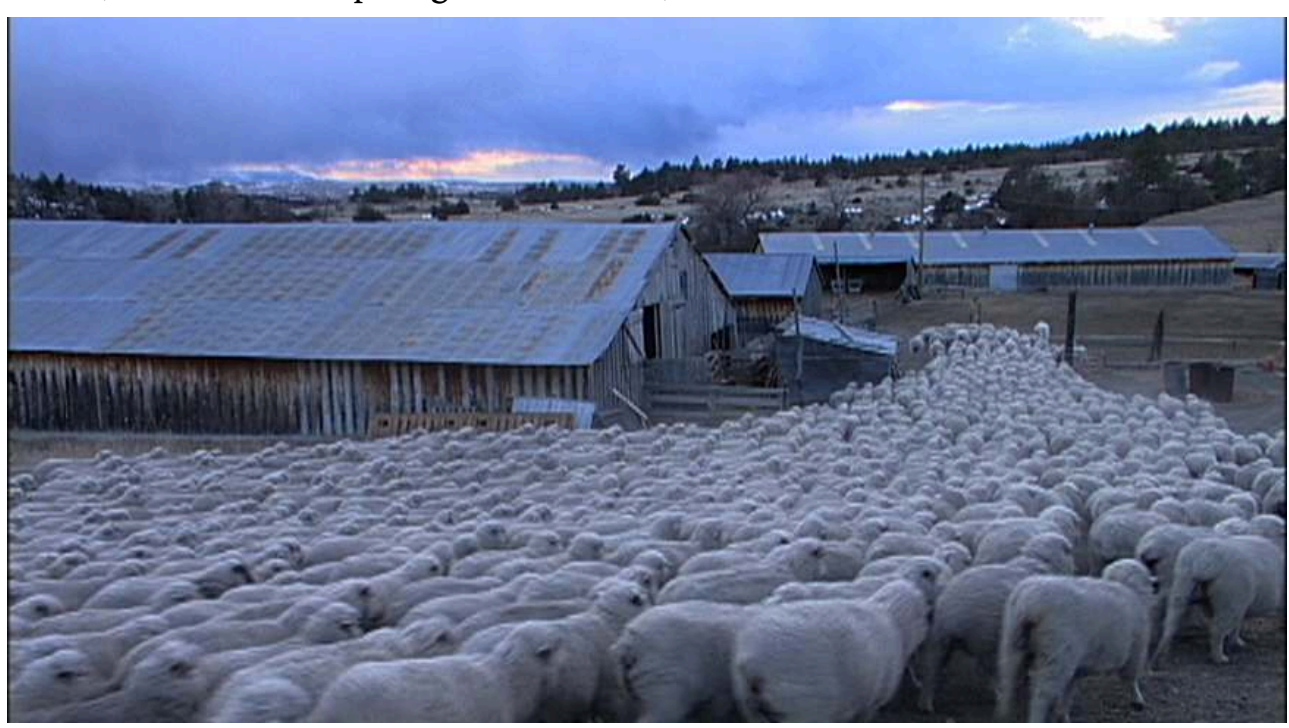

Photo Lucien Castaing-Taylor

5 Ensuite, je pense qu'il est également vrai de dire que les travaux qui ont émergé du SEL sont beaucoup plus soucieux de l'esthétique que ne le sont généralement les documentaires, et sont tout autant opposés au documentaire conventionnel à bien des égards. On s'oppose par exemple à l'usage journalistique des interviews, à la mise en 
scène des sujets qui parlent simplement de leur vies, ex post facto, plutôt que de les vivre; et à la gamme réductrice des structures narrative dramaturgique que déploient en général les documentaires, leur linéarité et leur prédilection pour la résolution et la clôture. En plus, SEL s'oppose aux répertoires étroits des styles qui sont sanctionnés par les gardiens de la pratique documentaire - en particulier l'hégémonie actuelle, un demi siècle après le fait d'un cinéma vérité quelque peu paresseux et laxiste, et la consécration par la police du film ethnographique d'une esthétique aveugle et insensible, réputée être "observationnelle ». Cette police, qui par la même occasion dénigre l'expérimental, la rigueur structurelle ou l'exigence stylistique en les reléguant au statut provincial d'avant-garde. Tout se passe comme si les gardiens de la flamme sacrée du cinéma ethnographique étaient totalement inconscients de tous les développements dans l'art et le film depuis les expérimentations en ethno-fiction de Jean Rouch dans les années ' 60 et ' 70.

Enfin, SEL s'oppose aussi - cette fois paradoxalement au nom de l'art et de son ambiguïté exégétique inhérente - ou pour le dire autrement au nom du figuratif et de son opacité, et contre le discursif et son désir de transparence -à la clarté et l'autosuffisance interprétative à laquelle l'anthropologie et le monde académique tendent généralement. SEL s'investit bien plus dans ce que John Keats, dans la fameuse lettre à son frère, caractérise si joliment de " capacité négative » - la capacité humaine quintessentielle d'être - je le cite, «dans les incertitudes, les mystères et les doutes, sans chercher de façon irritée la vérité et la raison ", [in uncertainties, mysteries, doubts without any irritable reaching after fact \& reason].

7 Concernant l'anthropologie, cela implique très certainement une relativisation de la « textologie culturelle », selon la phrase de Barbara Stafford, qui nous a été légué: par le tournant herméneutique de Clifford Geertz, et une interrogation renouvelée des abstractions clés comme la culture, la société, et le soi (tout du moins les représentations du soi), et un retour à la primauté de l'individu, du corps et par dessus tout l'expérience intersubjective et inter corporelle: - comme le fond de ce qui est pensé et de ce qui est dit, comme le fond à la fois de la signification et du symbolisme.

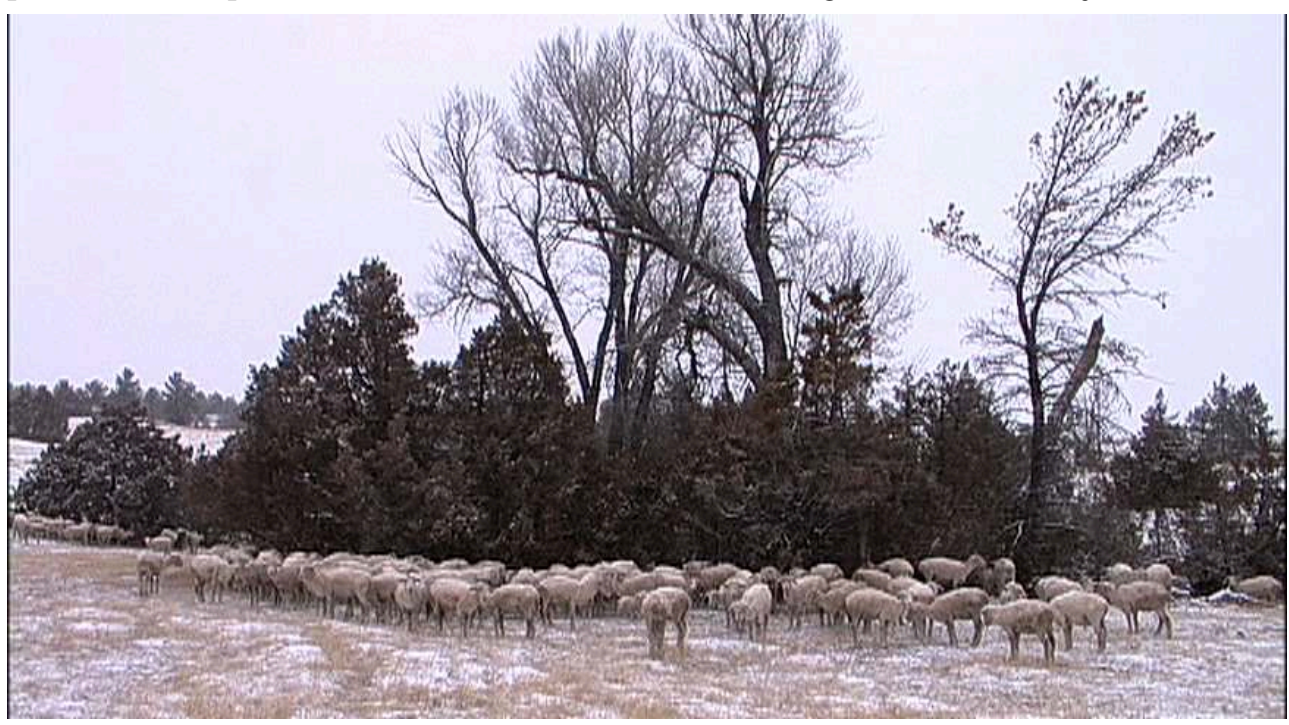

Photo Lucien Castaing-Taylor

Inutile de rappeler qu'il y a plus qu'assez de précurseurs dans cette voie, en plus de Dewey, Keats, et Merleau-Ponty. Dans la phrase de Mead et Bateson, il y a plus de 60 
ans, dans Balinese Character, c'est le domaine qu'ils appellent «apprentissage kinesthésique ». Dans l'expression plus récente de Michael Jackson, c'est celui de «la mimesis pratique ». C'est aussi, très certainement, le royaume du non verbal et du non discursif; ou dans les termes néo-kantiens de Michel Foucault, le visible (bien que pourquoi privilégier le visible? Disons plutôt à la place tout simplement le sensible) est l'in-dicible. Puisque le cinéma, la vidéo et l'art sonore ont tous une attache particulière à l'expérience qui diffère fondamentalement de celle de nos représentations écrites, comme l'a souligné Vivian Sobchack, particulièrement dans le déploiement de nos actes de déplacements, de notre audition, de notre vue, comme à la fois les structures originelles de l'existence incarnée et aussi les structures médiatisées du discours c'est je crois un moment propice pour l'audiovisuel, après un siècle d'exil, de revenir. De revenir et si ce n'est pas dans les rangs de l'anthropologie au moins, à tout prix, rentrer pleinement dans le combat anthropologique bien que cette fois sans endosser ce que l'on devrait appeler la désensibilisation de «la volonté de signifier » de sa discipline mère.

Comme je l'ai déjà mentionne, je vais montrer deux travaux, le premier étant bien plus exigeant que le second, des travaux que j'ai fait au SEL, bien que je dois préciser que je les ai filmés avant son existence, et qu'ils sont plus conventionnels et bien moins intéressants que les films qui sortent maintenant du Lab, fait par des camarades ouvriers comme JP Sniadecki, Stephanie Spray, Verena Paravel, et Diana Allan. Les deux sont des plans séquences, ou des plans séquences virtuels - Hell Roaring Creek, comme vous verrez, est un plan séquence mutilé, post-hoc, raté. Les deux montrent un investissement dans l'ontologie du réel (aussi bien qu'un engagement à la durée et un intérêt tout particulier pour ce qui peut être exprimé dans les limites d'une seule prise) qui mérite sûrement encore d'être qualifié de Bazinien.: À part cela ils se ressemblent peu, et c'est pourquoi je les ai installé dos-à-dos, contrairement à aujourd'hui, dans une boucle recto-verso.: Si le visible et l'invisible sont des "partageurs de secrets ", j'aime bien aussi penser ces deux travaux comme des partageurs de secret, pas simplement en tant que tel, mais aussi dans la chair de l'existence indéniablement non Cartésienne d'une Lebenswelt, à la foisanthropomorphique et post-humaine, dans lequel sujet et objet, celui qui perçoit ou celui qui est perçu, humains et animaux, biologie et culture, la forme et l' informe, l'amniotique et l'abject, l'Heimlich et le unheimlich, se mêlent.

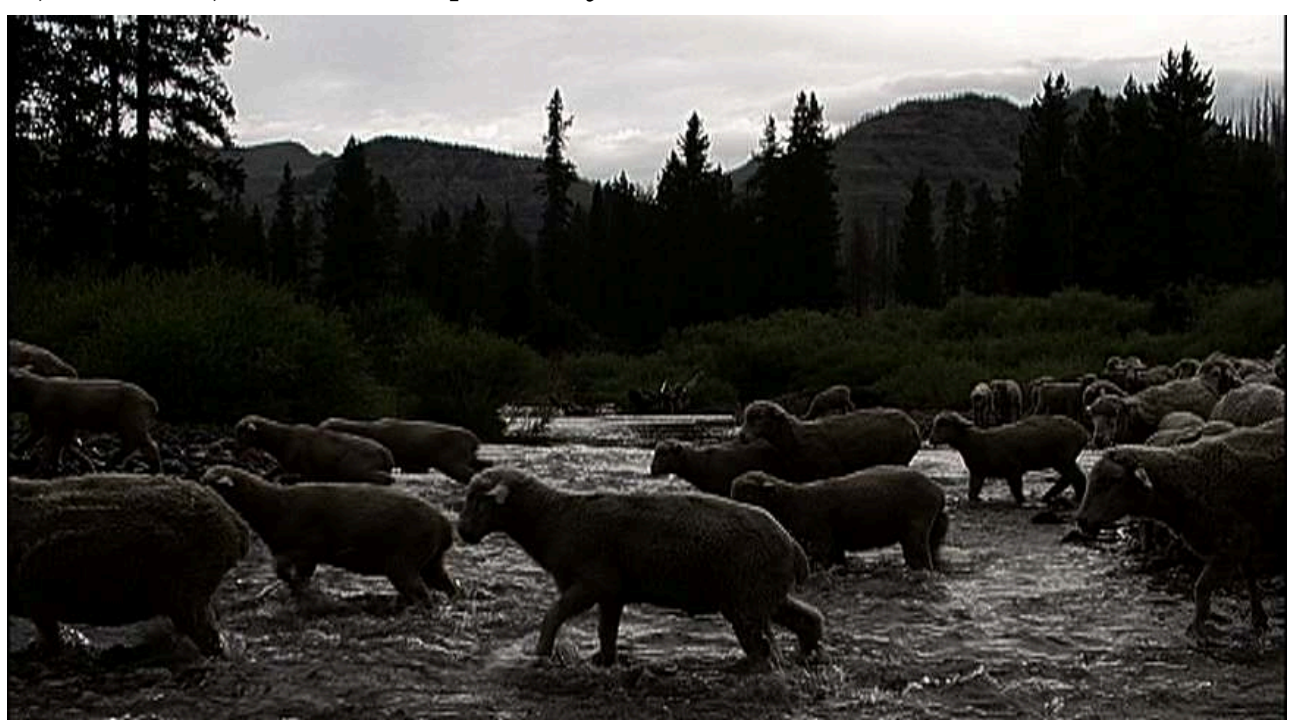

Photo Lucien Castaing-Taylor 
10 James Clifford a autrefois suggéré que, en tant que genre, l'ethnographie était le «pastoral » du vingtième siècle. Dans le plus large corps de ces travaux j'ai fait du pastoral mon sujet au sens le plus littéral possible. Comme mes prédécesseurs Hellénique, Romain, Européen, Asiatiques, et Africain, je « romantise » effrontément le pastoral sans me déconcerter, j'ai quand même: pensé à exprimer un certain sens de l'ambivalence avant cela, pour laisser de la place, comme Mary Douglas l'aurait fait, à la fois à la pureté et au danger, pour retenir la noirceur du soleil de Julia Kristeva. Mais ici l'abject n'est pas un cadavre, ou la révulsion ou le trauma que l'on ressent face à un corps qui se situe à l'extérieur de l'ordre symbolique, qui ne peut plus être un sujet pour nous. Ou peut-être qu'après tout c'est un cadavre, parce que dans la mode anthropologique rétro classique, j'ai décrit un mode de vie qui s'étiole et va s'éteindre, et en fait ce n'est pas plus que ça. Mais dans ce cas, dans «Into-the-jug ", le corps abject, loin de n'être plus un sujet, n'est pas encore un sujet, n'est pas encore, sauf pour les humains pour lesquels il doit toujours être le symbole biblique sur-determiné de l'agneau innocent gambadant. Ici, le corps abject est un agneau, ou plutôt une multitude d'agneaux, au seuil de la naissance, aux portes de la vie. Mais de quelles espèces vivantes parle-t-on? De quelle espèce de vie? D'une vie diversement médiatisée par l'humanité. C'est le Geworfenheit de Heidegger - l'être jeté au monde de toutes créatures, y compris des nôtres - dans toutes leur naissance liquide et liminale.

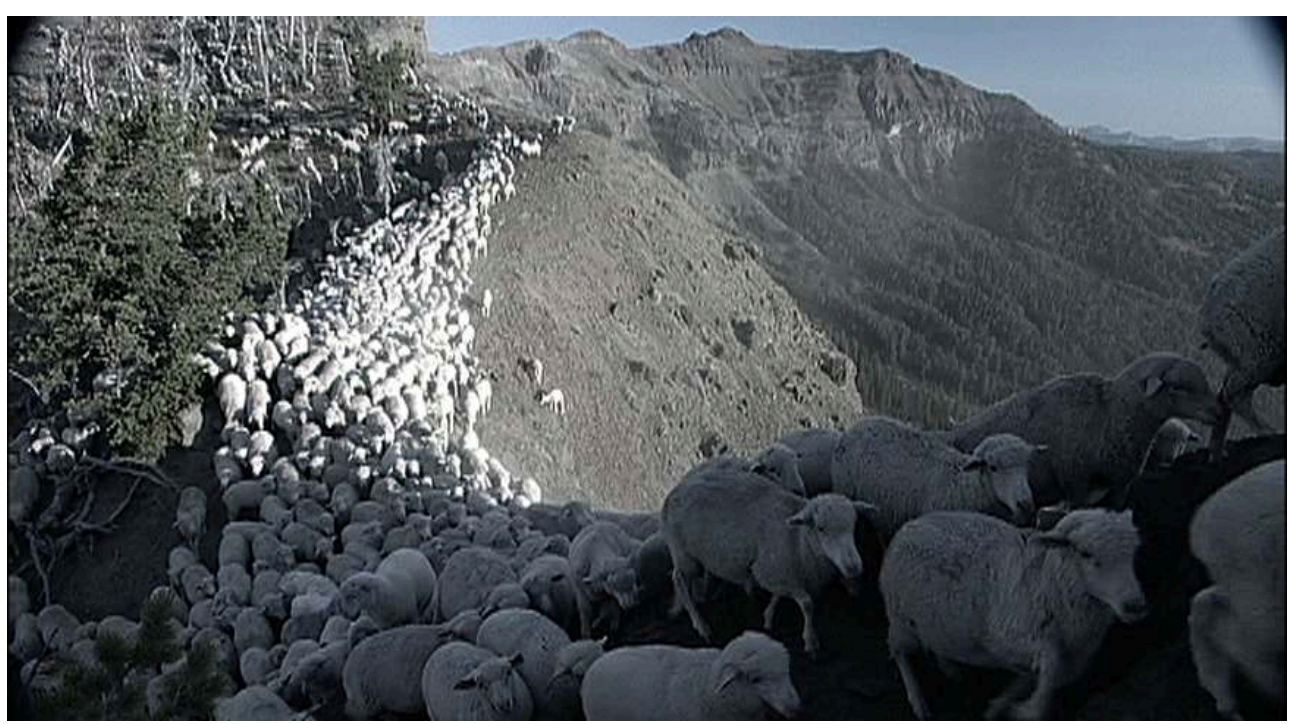

Photo Lucien Castaing-Taylor

\section{Discussion}

11 Arnd Schneider: The first one, Hell Roaring Creek, was probably filmed at dawn, in the early hours of the morning, and the only change in position of real time, with the camera you marked with the black "intertitles", so to speak, the black fillings. Now; I have a question: in the French presentation, this work is to be shown on multiple screens? Is that right?

12 Lucien Castaing-Taylor: I guess you asked two questions. One about the role of the black leader interposed in Hell Roaring Creek and the second one on how these works have been or could been installed. The black leader - it's a mistake and I cannot get it to work. Basically I went to Montana maybe 7 or 8 years ago and I started shooting a 
conventional long-form cinema vérité piece and one of the conventions of cinematography in fiction films and documentary is that you change camera angle, or you change focal length in order to facilitate editing or postproduction later. And actually while I was shooting this - it was dawn, c'était l'aube comme tu l'as dit. I was a "greenhorn" (blanc-bec), I was new, I did not have much experience with Rabelais' "moutons de Panurge", with 3000 sheep. And I said that's very beautiful and I will shoot at dawn and maybe see the sun coming up whether or not there is the sun. How long will it take? And I thought maybe it will take 2 minutes for 3000 sheep to cross the creek. I was wrong obviously: it took 30 minutes. And I began to doubt myself and after standing in the water, freezing, for about 5 minutes, 6 minutes of sheep crossing, I said this is unbearable. It's the most boring thing on the face of the earth. And I could have just cut and zoomed or moved. Instead I said that I will maintain a continuity of sound and I just zoomed in. But it's a really ugly zoom and I hate zooms. Je suis fidèle à Jean Rouch sur ce point là. Then I zoomed out later again with a loss of confidence and I think that this loss of confidence has massively compromised the structural rigor of that work, whatever possible virtual merit it has in some sense, I think. And I tried with strait cuts; I tried with 30 seconds of black as I tried in the installation at Marian Goodman Gallery in New York. I can't get it to work, I am sorry. I am still attached to it, much more than to the other pieces in a funny kind of way. There is something for me of the experience of the insufferable boredom on the one hand; the interminable multitude of the sheep crossing on the other. You couldn't really see it today with this projection. There is something like a phenomenological latitude: What is that? Is that an event or is a total non-event? There is a sort of fluctuating attention between fpaying attention to the whole, to the collectivity, and then attending to the particularities of individuals.

Public: I actually enjoyed watching it and I found it peaceful because I have personally sat on a rock in the middle of a river very long time like that. However I am curious to understand why if you found it really boring to be there why did you show it to us?

Lucien Castaing-Taylor: Obviously when I was filming I did not find it boring. But you know if you are an anthropologist in search of "significance" or what the American school call "meaning", you will get almost nothing. But if you are invested in lived experience, in the lebenswelt, in the lifeworld, the fact that it takes 30 minutes for sheep and shepherds get across the creek involves a pretty intense relationship to space and time, especially to time. Here we have two different rivers cross cutting each other. Sorry if I used the word boredom.

Arnd Schneider: If I may just interject briefly. It is of course also a decision of what position you take as a filmmaker and cameraman. Because I remember when doing field work in Sicily I once followed the transhumance of a cattle in the mountains. It was a stampede that lasted a whole day and I was immersed trying to film that. It is very hard and ultimately I did not succeed. If you have a fixed camera position that's very different, you have the viewpoint to take an angle.

Public: I did not find the first film boring at all. I think it would be more interesting if you had shown the second film at first. Because the first one is appeasing, it is the passage of time. It is a metaphor and I see it that way artistically. It is a metaphor for life. We have to pass across the stream to go somewhere else. We don't know where they come from and where they are going to. The second film is so hard on us. It is a sort of initiation for us to see this brutality. Somehow, I feel that if you show the second 
one first, as a performance it might be more appeasing. I noticed a young girl who was sitting in the audience and she couldn't look at it, so she went out.

Lucien Castaing-Taylor: If there is a performative aesthetic to it, it is a performative aesthetic of non-performance. I think you're wrong. The second one is very hard to watch and if you had watched "into the jug" first you would have felt an assault on your being that would have compromised your ability to respond, more contemplatively, to "Hell Roaring Creek."

Public: I like both films but I would like to ask you about your position. In the first piece you were outside the situation and in the second you were inside. That was my feeling. Even though you've found this crossing quite intense, you were observing detainees of sheep, characters, but you were not following this. Can you say something about your position?

Lucien Castaing-Taylor: I cannot recreate what I was thinking when I was filming in that regard. The first one is not on the tripod; I was holding it as still as I could. So there is a kind of withdrawal of my subjectivity holding it as if it were on a tripod. Even if I am downstream or in the stream, at a certain distance from the sheep and the sheep are not coming towards me, there is no space activating the access to the camera. It is a kind of "pictorialisation." a "spectacularisation". In the second one there is a mobile camera, it is moving and it this is clearly handheld. I start outside the jug and then I end up in it. The other difference is that in the first one there is no embodied guttural intimate human sound. None of the humans are wearing wireless microphones and in the second one the main character was wearing a wireless microphone. In the second one you have embodied guttural human sounds. But the first one is not entirely disembodied. I have a kind of outer-body experience. I really felt that I reconnect with nature. Subjectively I start engaging with the sheep, with this landscape and with this river in a way that takes me out of my immediate bodily experience. I don't think there's a clear-cut distinction between the two.

\section{RÉSUMÉS}

Lucien Castaing-Taylor, à partir de la projection de deux de ses films récents sur la temporalité, pose la question de leurs relations avec l'art et l'anthropologie. Ces travaux font partie d'un projet plus vaste qui est une ode a l'Ouest américain - une évocation sensorielle de la vie des derniers bergers qui, l'été, guident leurs troupeaux à travers les pâturages de la montagne de Bear Tooth au Montana. Sans voix-off et ne cédant à aucun compromis, les films révèlent un monde dans lequel la nature et la culture, les animaux et les humains, les paysages et les climats, la vulnérabilité et la violence sont intimement liés.

Lucien Castaing-Taylor explores the relationship between two of his recent films that deal with temporality and art and anthropology. These two works are part of a more extensive project, an ode to the American west - a sensory evocation of the lives of the last shepherds to guide their herds up the Bear Tooth Mountains in Montana toward the pastures for the summer. Uncompromising and stripped of any voiceover, his project reveals a world in which nature and 
culture, animals and humans, landscapes and climates, vulnerability and violence are brought together intimately.

\section{AUTEUR}

\section{LUCIEN CASTAING-TAYLOR}

Cinéaste, artiste et anthropologue, Lucien Castaing-Taylor a récemment mené à terme une série de huit installations vidéo utilisant différents registres stylistiques pour évoquer l'attraction et l'ambivalence de la vie rurale en juxtaposant des paysages monumentaux et mythologiques de l'Ouest américain avec plusieurs prises de son rapproché et synchrone. Parmi les publications de Castaing-Taylor : Visualizing Theory (ed., Routledge, 1994), Cross-Cultural Filmmaking (avec Barbash, University of California Press, 1997), Transcultural Cinema, une collection d'essai du cinéaste David MacDougall (ed., Princeton University Press, 1998), et The Cinema of Robert Gardner (coed., avec Barbash, Berg, 2008). Il a été un des fondateurs de la revue de l'American Anthropological Association, le Visual Anthropology Review (1991-94). Lucien Castaing-Taylor est directeur du Film Study Center et du Laboratoire d'ethnographie sensorielle à l'Université de Harvard. 